Saeculum Christianum

vol. XXIII (2016)

pp. 23-34

TOMASZ SKIBIŃSKI SAC

WNHiS UKSW, Warszawa

\title{
LETTERS OF RECOMMENDATION OF SIDONIUS APOLLINARIS - THE LEGACY OF TRADITION AND THE CHALLENGE OF TRANSFORMATIONS
}

Sidonius Apollinaris, a Gallic aristocrat and a bishop of Augustonemetum, the capital of Auvergne, left a collection of 147 letters collected in 9 books as his literary heritage ${ }^{1}$. It has been pointed out many times that the songs are written in very sophisticated prose, full of rhetorical means, and the author himself states that these are selected, reviewed and corrected lists in terms of publication ${ }^{2}$. From the point of view of the content, they are poor, but they provide a lot of information to learn about the relations prevailing in Gaul in the fifth century ${ }^{3}$. A lot of them are letters of recommendation, that are part of the tradition of late antique and early medieval epistolography. In ancient times, the use of litterae commendatitiae is a phenomenon that is both common and normal, as well as necessary for obtaining privileges or functions. These letters were an expression of power and political influence and fit perfectly into the hierarchical nature of the ancient community with its patronage system ${ }^{4}$.

The purpose of this article is to examine Sidonius Apollinaris' letters of recommendation in terms of their functions, models, arguments used, accents and addressees of the letters, as well as the changes that took place during Sidonius' life in Gaul and the author himself's.

\footnotetext{
1 In this study we use the following translation and edition of the work: Sidonius Apollinaris, Epistulae, ed. A. Loyen: Sidoine Apollinaire, vol. 2: Correspondance livres 1-5, vol. 3: Correspondance livres 6-9, Paris 2003; translated by M. Brożek: Sydoniusz Apolinary, Listy i wiersze, Polska Akademia Umiejęności. Biblioteka przekładów z literatury starożytnej 14, Kraków 2004. [TN English translation of the quotes: Sidonius Apollinaris, Letters. Tr. O.M. Dalton (1915)]

2 Sidonius' letters were prepared for publication in three collections. The first - containing books I-VII was prepared at the request of Constantius (cf. Sidonius Apollinaris, Epistula I 1,1, ed. Loyen, vol. 2, p. 2; ibidem, VII 18,1, ed. Loyen, vol. 3 , p. 79). This original collection was later expanded to include further books: the eighth - prepared at the request of Petronius (cf. Ibidem VIII 1.1, ed. Loyen, vol. 3, p. 82; VIII 16.1, ed. Loyen, vol. 3, pp. 127) and the ninth - at Firmus' request (cf. Ibidem IX 1, ed. Loyen, vol. 3, pp. 130-131; IX 16.2, ed. Loyen, vol. 3, p. 178).

3 Cf.C. Moreschini, Letteratura cristiana delle origini greca e latina, Roma 2007, p. 211; S. Pricoco, Sidonio Apollinare, w: Patrologia, vol. 4. Dal Concilio di Calcedonia (451) a Beda. I Padri Latini, ed. A. Di Berardino, Genova 1996, p. 268.

4 Cf.L. Furbetta, La lettre de recommandation en Gaule ( $V^{\mathrm{e}}-V I \mathrm{I}^{\mathrm{e}}$ siècles) entre tradition littéraire et innovation, w: Gouverner par les lettres, de l'antiquité a l'époque contemporaine, ed. Bérenger-O. Dard, Metz 2015, p. 347. The author of this article addresses the issue of letters of recommendation in Gaul in the period of V-VII century, he briefly discusses the structure and political functions of selected letters of recommendation from the following authors: Sidonius Apolinary, Ruricius I of Limoges, Avitus of Vienne, Venantius Fortunatus, Didier of Cahors; cf. L. Furbetta, La lettre, pp. 347-368.

5 During Sidonius' life, the transition from Roman Gaul to Gaul tribal states and from the world of Roman state structures to a world based on structures developed and proposed by the Catholic Church is made. Sidonius himself
} 
Our author has a sense of belonging to the group of leading citizens ${ }^{6}$. It was also associated with a sense of superiority, mutual respect, carefully nurtured friendship and - which will be the subject matter of the analysis - the mutual support resulting from them.

At a young age, Sidonius started public activity and continued it - albeit with breaks - until 469. This commitment also resulted from a sense of responsibility towards the community? He was prepared for public activity from a young age and was proud of it, we find several letters in his correspondence in which he reminds of these duties and also of his colleagues who tried to avoid them.

An example of such an appeal is a letter to Eutropius, in which he explains at the very beginning that his goal is to free the recipient from the bottom of domestic incapacitation and call him to take up service in the imperial ranks.

Having also presented extensive arguments that were supposed to induce and in fact prompted the addressee to this service ${ }^{9}$, he assures: If you accept the encouragement, I will be your ally and helper, guide and participant in your efforts ${ }^{10}$. Sidonius does not explain what this promised help would involve, we also do not know whether it was really needed in this particular case and whether our author could fulfil his promise. Epistulae commendatitiae provides more specific information on the scope and nature of mutual assistance and support as well as its conditions.

The letters of recommendation ${ }^{11}$ are generally intended to move the recipient, to make him show special help to the recommended person. As such, they require the author to skilfully juxtapose three entities: the patron who is the author of the letter; the recommended person (commendatus) for whom the author asks for help; the recipient, who under the influence of the letter, himself becomes a patron, if he agrees to grant the expected gift. As for the structure,

in the first part of his life also takes on the duties of an aristocrat and state service, in 469 he abandons them in favour of the spiritual service, becoming a bishop approx. in 471. To learn more about this transition, see J. Grzywaczewski, The Passage from Romanitas to Christianitas According to Sidonius Apollinaris († c. 486), „Studia patristica", 48/2010, pp. 295-302; ibidem, Christianity of Gaul according to Sidonius Apollinaris (c. 430-486), „Forum Teologiczne”, 11/ 2010, pp. 127-139.

6 Cf. Sidonius Apollinaris, Epistula V 17,4, ed. A. Loyen, vol. 2, p. 202, trans. M. Brożek, p. 100. J. Styka notes that the aristocracy depicted in Sidonius' correspondence also had a sense of alienation in the flood of barbarism spreading towards which he adopted an attitude of elitism and distance. Cf. J. Styka, Sydoniusz Apollinaris i kultura literacka w Galii V wieku, „Prace Komisji Filologii Klasycznej PAU”, no 38, Kraków 2008, 261. More on the topic cf. ibid, pp. 261-275.

7 As far as Sidonius' perception of public activity is concerned, see Ibidem, p. 299-310.

8 Scribendi causa uel sola uel maxima, quo te scilicet a profundo domesticae quietis extractum ad capessenda militiae Palatinae munia uocem; Sidonius Apollinaris, Epistula I 6,1, ed. A. Loyen, vol. 2, p. 18; trans. M. Brożek, p. 11. [TN English translation of the quote: Sidonius Apollinaris, Letters. Tr. O.M. Dalton (1915)]

9 In the collection of letters bequeathed by Sidonius, there is another surviving one addressed to Eutropius, in which he congratulates his friend on the position of the prefect of Gaul and also notices in this promotion his merits with satisfaction; cf. ibidem III 6, ed. A. Loyen, vol. 2, pp. 93-94.

10 Si pateris hortantem, conatuum tuorum socius adiutor, praeuius particeps ero; ibidem I 6,5, ed. A. Loyen, vol. 1, p. 19, trans. M. Brożek, p. 11. [TN English translation of the quote: Sidonius Apollinaris, Letters. Tr. O.M. Dalton (1915)]

11 L. Furbetta (La lettre, p. 348) draws attention to the scheme of the letter of recommendation developed by Cicero, which is the most complete and remains a model for many later authors. See also R. Andrzejewski, Struktura antycznego listu polecajacego świetle zasad retoryki,, "Roczniki Humanistyczne", 21/1973, from col. 3, pp. 17-24 (the author discusses the structure of an ancient letter of recommendation based on examples taken from the works of Cicero and Gregory of Nazianzus); the same, Cicero's letters of recommendation in the light of ancient principles of recommendation, "EOS", 63/1975, pp. 43-58. 
letters of recommendation generally contain three parts: the name of the recommended person and his relationship with the author of the letter, presentation of the recommended person to the recipient, request and motivation ${ }^{12}$. Sidonius also follows this structure of the letter. For already in the first letter of the collection, Sidonius indicates his epistolographic models and masters: Cicero, Pliny the Younger, Symmachus and Julius Titianus ${ }^{13}$, and he imitates them both in his collection in the style of expression as well as in the structure of letters and the issues discussed ${ }^{14}$.

An example of a letter of recommendation is a letter from Sidonius to Sagittarius, to whom the author recommends Projectus ${ }^{15}$. We know neither the addressee of the letter nor Projectus who was recommended to him. On the basis of the letter, we can learn more about the case itself, which is the subject of intercession, and about the people involved in it. In the first part of the letter we read:

The honourable Projectus is ardently bent upon your friendship; I trust that you will not repel his advances. He is of noble lineage; the reputation of his father and his uncle, and his grandfather's eminence in the Church unite to lend a lustre to his name; he has indeed all that conduces to distinction; family, wealth, probity, energetic youth; but not till he is assured of your good graces, will he consider himself to have attained the culminating point of his career. Although he has already asked and obtained from the widow of the late honourable Optantius her daughter's hand----may God speed his hopes----he fears that little will have been gained by all his vows, unless his own solicitude, or my intercession gains him your support as well ${ }^{16}$.

The introduction of the letter is very simple. Sidonius begins directly with the presentation of the recommended Projectus ${ }^{17}$. He describes him with the title vir clarissimus emphasising the nobility of origin, which is also further underlined by the presentation of ancestors and relatives. Sidonius emphasises four important features of Projectus: the splendour of the family, the nobility of morals, the property inherited from their ancestors, and youthful enthusiasm for all honourable activities. They are the arguments that he treats as relevant and sufficient to recognise the young man as worthy of his command and belonging to a group of Sagittarius people.

12 Cf. L. Furbetta, La lettre, pp. 347-348.

13 Sidonius Apollinaris, Epistula I 1,1-2, ed. A. Loyen, vol. 2, p. 2.

14 Cf. L. Furbetta, La lettre, p. 349.

15 The letter most probably originates from 469 r. Cf. A. Loyen, Chronologie des lettres, in: Sidoine Apollinaire, vol. 2: Correspondance livres 1-5, Paris 2003, p. 246.

16 Vir clarissimus Proiectus, domi nobilis et patre patruoque spectabilibus, auo etiam praestantissimo sacerdote conspicuus, amicitiarum tuarum, nisi respuis, auidissime sinibus infertur, et cum illi familiae splendor probitas morum, patrimonii facultas, iuuentutis alacritas in omne decus pari lance conquadrent, ita demum sibi tamen uidebitur ad arcem fastigatissimae felicitatis euectus, si gratiae tuae sodalitate potiatur; Sidonius Apollinaris, Epistula II 4,1, ed. A. Loyen, vol. 2, p. 55, trans. M. Brożek, p. 29. [TN English translation of the quote: Sidonius Apollinaris, Letters. Tr. O.M. Dalton (1915)]

17 R. Andrzejewski (cf. Struktura antycznego listu polecajacego, pp. 18-19) pointed out in his study that in the light of the rhetorical principles, two types of introductions were used in letters of recommendation: simple introduction, which was only the introduction of the recommended person, and extended introduction, which consisted of two parts: preparation of the recipient for friendly treatment of the author's requests and those from the recommended person. In this particular case, Sidonius definitely chooses the first form, i.e. simple introduction. 
The second part of the letter is devoted to the presentation of the subject matter. Projectus is seeking the hand of a young lady, daughter of the late Optantius. He has already obtained the consent of her mother for this marriage, but he also wants to ask for the consent of Sagittarius, who is the guardian of his chosen one ${ }^{18}$.

In the last part, the author spares no compliment to Sagittarius, emphasising his high position and decency of the house - it is also an element widely present in letters of recommendation aimed at obtaining the kindness of the addressee (captatio benevolentiae); he also encloses a personal request to Sagittarius for help to Projectus in the presented case:

And since it is but natural that your admirable government of your household should attract men of the right stamp even from distant places, reward the modesty of this suppliant wooer by a kindly response. In the usual course of events it would have fallen to you to obtain him the mother's consent; as it is, he saves you this trouble, and you have only to sanction a troth already approved. Your reputation gives you in effect a parental authority in regard to this match; the father himself, if he had lived, could not have claimed a greater. Farewell ${ }^{19}$

We do not know how the fate of Projectus turned out and how it was received by Sagittarius, but in the collection of Sidonius we find a short letter to Pegasus about Menstruanus, which is probably a response to the recommendation of the latter to Sidonius ${ }^{20}$. Sidonius is pleased to inform the addressee that Menstruanus - checked up on by Pegasius for a long time deserved to be included among the people dear to us $^{21}$. There is no mention of the noble origin of the recommended person, but the list of Menstruanus' character traits is worth emphasising since they convinced Sidonius to make the above-cited decision: nice and polite, modest and sober, economical, obligatory - all this means that: accepted for friendship with respectable people he does no more benefit than he gives ${ }^{22}$. This nobility is again noticed

18 Optantii clarissimi uiri nuper uita functi filiam, quod deo prosperante succedat, licet a matre pupillae in coniugium petierit obtinueritque, parum tamen uotorum suorum promotum censet effectum, nisi assensum tuum super his omnibus seu sedulitate sua seu precatu nostrae intercessionis adipiscatur. Namque ipse, quantum ad institutionem spectat puellae, in locum mortui patris curarum participatione succedis, conferendo virgini parentis adfectum, patroni auctoritatem, tutoris officium; Sidonius Apollinaris, Epistula II 4,2, ed. A. Loyen, vol. 2, p. 55. [TN English translation of the quote: Sidonius Apollinaris, Letters. Tr. O.M. Dalton (1915)]

19 Quocirca, quia dignus es ut domus tuae celeberrimam disciplinam etiam procul positorum petat ambitus, sicut decet bonarum partium uiros, benignitate responsi proci supplicis uerecundiam munerare et, qui ita expetitus deberes illi expetere pollicendam, securus permitte promissam, quia sic te condicioni huic meritorum ratio praefecit, ut nec superstiti Optantio in liberos suos decuerit plus licere. Vale; Ibidem II 4,3, ed. A. Loyen, vol. 2, p. 55-56, translation into Polish by M. Brożek, 29-30. [TN English translation of the quote: Sidonius Apollinaris, Letters. Tr. O.M. Dalton (1915)]

20 We do not have a letter of recommendation sent by Pegasius, but the fact of recommendation is evidenced by the sentence in the second part of the letter, in which Sidonius becomes an exponent of the Arvernis' joy: because I find that they [Menstruanus] liked what you praised; [quibus hoc in eo placuisse confirmo, quod te probasse non ambigo]; Ibidem II 6.2, ed. A. Loyen, vol. 2, p. 58, translated by M. Brożek, p. 30 . [TN English translation of the quote: Sidonius Apollinaris, Letters. Tr. O.M. Dalton (1915)].

21 Menstruanus amicus tuus longo istic tempore inspectus meruit inter personas nobis quoque caras deuinctasque censeri; ibidem II 6,1, ed. A. Loyen, vol. 2, p. 58, translated by M. Brożek, p. 30. . [TN English translation of the quote: Sidonius Apollinaris, Letters. Tr. O.M. Dalton (1915)]

22 Opportunus, elegans, uerecundus, sobrius, parcus, religiosus et his morum dotibus praeditus ut, quotiens in boni cuiusque adscitur amicitias, non amplius consequatur beneficii ipse quam tribuat; ibidem II 6,1, ed. A. Loyen, vol. 2, p. 58, trans. by M. Brożek, p. 30. [TN English translation of the quote: Sidonius Apollinaris, Letters. Tr. O.M. Dalton (1915)] 
in the final part of the letter, in which we read: and the third reason [to joy] he has himself, that in him all the honourable recognise everything honourable $e^{23}$.

In the second part of the letter, Sidonius also congratulates his friend: that you manage to raise friends or choose such friends ${ }^{24}$. This sentence, emphasising the nurturing and conscious selection of friendship, is another testimony to the elitism of the aristocracy group represented by Sidonius.

The letter I 10 to Campanianus also contains an interesting recommendation ${ }^{25}$ :

The Intendant of Supplies has personally presented the letter in which you commend him as your old friend to my new judgement. I am greatly indebted to him, but most of all to yourself for this evidence of your resolve to assume my friendship certain and proof against all suspicion. I welcome, I eagerly embrace this opportunity of acquaintance, and of intimacy, since my desire to oblige you cannot but draw closer the bonds which already unite us. But please commend me in my turn to his vigilant care, commend, that is, my cause and my repute.

For I rather fear that there may be an uproar in the theatres if the supplies of grain run short, and that the hunger of all the Romans will be laid to my account. I am on the point of dispatching him immediately to the harbour in person, because news is to hand that five ships from Brindisi have put in at Ostia laden with wheat and honey. A stroke of energy on his part, and we should have these cargoes ready in no time for the expectant crowds; he would win my favour, I the people's, and he and I together yours. Farewell ${ }^{26}$.

The letter was written at the time when Sidonius was the prefect of Rome and is a response to another one, in which Campanianus recommends the delivery of the letter to his friend acting as a head of supply (praefectus annonae). The first part of the letter focuses on the friendship of Sidonius and Campanianus, and is constructed according to the classical model of the letters of Cicero, Pliny and Symmachus, emphasising the importance of friendship and the obligations arising from $\mathrm{it}^{27}$. In the second part, however, the letter changes the host person into the recommended person, and Sidonius places a kind of self-recommendation

\footnotetext{
${ }^{23}$ illi tertia, de quo boni quique bona quaeque iudicauerunt; ibidem II 6,2, ed. A. Loyen, vol. 2, p. 58, translated by M. Brożek, p. 30 . [TN English translation of the quote: Sidonius Apollinaris, Letters. Tr. O.M. Dalton (1915)]. Similar letters of characteristics of recommended persons appear also in other letters of Sidonius, as in the letters of Quintus Symmachus, whom Sidonius recognises as his master in epistolography; see P. Heather, Upadek Cesarstwa Rzymskiego translated by J. Szczepański, Poznań 2007, p. 31.

${ }_{24}$ Cui amicos sic aut instituere aut eligere contingit; Sidonius Apollinaris, Epistuala II 6,2, ed. A. Loyen, vol. 2, p. 58, translated by M. Brożek, p. 30.

25 This presentation contains some elements of the letter analysis found in: L. Furbetta, La lettre, p. 350-351.

26 Accepi per praefectum annonae litteras tuas, quibus eum tibi sodalem ueterem mihi insinuas iudici nouo. Gratias ago magnas illi, maximas tibi, quod statuistis de amicitia mea uel praesumere tuta uel inlaesa credere, ego uero notitiam uiri familiaritatemque non solum uolens sed et auidus amplector, quippe qui nouerim nostram quoque gratiam hoc obsequio meo fore copulatiorem. Sed et tu uigilantiae suae me, id est famae meae statum causamque commenda. Vereor autem ne famem populi Romani theatralis caueae fragor insonet et infortunio meo publica deputetur esuries. Sane hunc ipsum e uestigio ad portum mittere paro, quia comperi naues quinque Brundisio profectas cum speciebus tritici ac mellis ostia Tiberina tetigisse; quarum onera exspectationi plebis, si quid strenue gerit, raptim faciet offerri, commendaturus se mihi, me populo, utrumque tibi. Vale; Sidonius Apollinaris, Epistula I 10, ed. A. Loyen, vol. 2, p. 33, translated by M. Brożek, p. 18. [TN English translation of the quote: Sidonius Apollinaris, Letters. Tr. O.M. Dalton (1915)].

27 Cf. L. Furbetta, La lettre, p. 350.
} 
in it, asking the addressee for help; presents his fears of being found guilty of neglecting Rome's supply. So, he announces that he intends to send the recommended head of supply to the port, where ships carrying the cargo of grain and honey had arrived. If the intendant does well and obtains these goods for the people, he will show his friendship and obtain the friendship of Sidonius, just as Sidonius will grant the people's kindness. In this way, Sidonius builds a picture of the reciprocity of favours performed and those favoured by others.

Petronius is also an addressee of short letters of recommendation, at whose request the bishop of Augustonemetum prepared the eighth book of his letters for publication.The first one (II 5) probably originates from 469 and was created in Lyon ${ }^{28}$. Here is its content:

John, my friend, is caught inextricably in the labyrinth of a complex business, and is at a loss what to hope and what abandon until your experienced eye, or another as good (if such there be), has looked into his titles to determine their validity. The case is confusing in that it has more than one side, and he does not see whether his statement should maintain one line of action or impugn another.

I most earnestly beg you, therefore, to examine his documents and tell him what his rights are, what he ought to allege or refute, and what his procedure should be. Let but the stream of this affair flow from the springs of your advice, and I have no fear that the other side will manage to reduce its volume by any unfair diversion. Farewell. ${ }^{29}$

It is basically a short note announcing an "unsolvable maze of a complicated court case", without any preamble or discussion of the case, and expressing the belief that Petronius or someone with similar knowledge can help solve the problem. Hence the request of Sidonius for help to John and the conviction expressed at the end that no opponent would challenge the case which would be based on the advice of Petronius. As we can see, there is no other reason for the request as soon as the addressee's difficulty and knowledge and authority arose. No features of the recommended person are mentioned here.

Sidonius writes a letter to one scholar, Tetradius, recommending a young student. Commendatus is a man of good family, but quite as much ennobled by his admirable modesty as by his high descent ${ }^{30}$.

However, not all the people recommended by Sidonius deserve such favourable opinions. With some embarrassment, Sidonius turns to Riotam, the ruler of the Britons, to help the letter dispatcher recover the abducted slaves, although he does not hide that he is a man from another social group and in the light of reading it is difficult to even imagine any closer relations between him and Sidonius. The presentation of the recommended one not only fails to indicate any of its positive qualities, but on the contrary defines him as follows: a letter

\footnotetext{
28 Cf. A. Loyen, Chronologie des lettres, Sidoine Apollinaire, vol. 2, p. 247.

29 Iohannes familiaris meus inextricabilem labyrinthum negotii multiplicis incurrit et donec suarum merita chartarum uel uestra scientia uel si qua est uestrae (si tamen est ulla) similis inspexerit, quid respuat, quid optet ignorat. Ita se quodammodo bipertitae litis forma confundit, ut propositio sua quem actionis ordinem propugnatura, quem sit impugnatura, non nouerit. Pro quo precem sedulam fundo, ut perspectus chartulis suis si quid iure competit instruatis, quae qualiterue sint obicienda, quae refellenda monstrantes. Non enim uerebimur quod causae istius cursus, si de uestri manauerit fonte consilii, ulla contrastantum deriuatione tenuetur. Vale; Cf.Sidonius Apollinaris, Epistula II 5, ed. A. Loyen, vol. 2, p. 57, translated by M. Brożek, p. 30.

30 Vir clarissimus Theodorus, domi quidem nobilis, sed modestissimae conuersationis opinione generosior; ibidem III 10,1, ed. A. Loyen, vol. 2, p. 99, translated by M. Brożek, p. 50. [TN English translation of the quote: Sidonius Apollinaris, Letters. Tr. O.M. Dalton (1915)].
} 
carrier, simpleton, dark, wicked [...] distressed simpleton, stranger, poor ${ }^{31}$. Sidonius writes a letter, being aware that the matter is difficult and, on the one hand, he can expose himself to it and, on the other, he acknowledges that he should not remain silent ${ }^{32}$.

His ordination, especially the assumption of episcopate, changes a lot in his life. The nature of his correspondence also changes then, and letters of recommendation are addressed almost exclusively to his colleagues in the episcopate and are primarily aimed at solving various legal matters that belonged to the bishop's duties and to help his subordinates. On the one hand, this testifies to Sidonius' significant position in the Gallic church as an organisation ${ }^{33}$, and on the other, to the role of church representatives in a society building its new structures on the ruins of the falling Roman Empire ${ }^{34}$. After ordination of bishop Sidonius, there are no letters of recommendation dealing with political career or public functions ${ }^{35}$. Instead, there are frequent letters of recommendation for clergy or people associated with the church community.

An example of a letter from this period is the letter III 5 to Hypatius ${ }^{36}$, in which Sidonius recommends Donidius, a admirable man (vir spectabilis), to him. This is a letter from the beginning of the episcopate (turn of the years 470/471), still bearing significant similarities to letters from the secular period of Sidonius' life. The bishop uses the pattern we already know, which includes: the name of the recommended person and his relationship with the author of the letter, presentation of the recommended person to the recipient, request and motivation - but the distribution of accents is different from what we saw in the analysed works. Here is the content of the letter:

The excellent Donidius admires and respects your character; and had he no other aim than his own family advantage, he might safely confide in your acknowledged reputation, and feel no need of another's advocacy. But he thinks so well of me, that he would have me ask for him what he could certainly obtain alone. Consequently, you will

\footnotetext{
31 The entire text fragment: Gerulus epistularum humilis obscurus despicabilisque etiam usque ad damnum innocentis ignauiae mancipia sua Britannis clam sollicitantibus abducta deplorat. Incertum mihi est an sit certa causatio; sed si inter coram positos aequanimiter obiecta discingitis, arbitror hunc laboriosum posse probare quod obicit, si tamen inter argutos, armatos, tumultuosos, uirtute, numero, contubernio contumacem poterit ex aequo et bono solus, inermis, abiectus, rusticus, peregrinus, pauper audiri; ibidem III 9,2, ed. A. Loyen, vol. 2, p. 98, translated by M. Brożek, p. 50. Cf. Epistula IV 7, where Sidonius, on the one hand, expresses his contempt to the character and behaviour of the letter messenger, yet he acknowledges his service necessary to show respect to friends via letters huiuscemodi saepe personae despicabiles ferme sunt, in sodalibus tamen per litteras excolendis dispendii multum caritas sustinet, si ab usu frequentioris alloquii portitorum uilitate reuocetur; ibidem IV 7,3, ed. A. Loyen, vol. 2, p. 127, translated by M. Brożek, p. 65. [TN English translation of the quote: Sidonius Apollinaris, Letters. Tr. O.M. Dalton (1915)]

32 Ea semper eueniunt de quibus loci mei aut ordinis hominem constat inconciliari, si loquatur, peccare, si taceat; [but things seem to be always happening which a man of my order and in my position can neither mention without unpleasantness, nor pass over without neglect of duty]; ibidem III 9,1, ed. A. Loyen, vol. 2, p. 98, translated by M. Brożek, p. 50. [TN English translation of the quote: Sidonius Apollinaris, Letters. Tr. O.M. Dalton (1915)].

33 Cf. M. Brożek, Wstęp, in: Sydoniusz Apolinary, Listy i wiersze, s. VII.

34 For more on the position of bishop in Gaul during this period, see in: M. Sas, Pozycja i rola biskupa w mieście galijskim w upadajacym Zachodnim Cesarstwie Rzymskim - analiza dziet Sydoniusza Apollinarisa, „Teka historyka", 38/2009, pp. 311-320.

35 Cf. L. Furbetta, La lettre, p. 351.

36 The letter was written at the end of 470 or early 471, cf. Loyen, Chronologie des lettres, in: Sidoine Apollinaire, vol. 2, pp. 249.
} 
acquire a crowning title of distinction in making both of us your debtors, though one alone will reap the material benefit.

He seeks to acquire the other moiety of the estate of Eborolacum, abandoned even before the barbarian came, but now in possession of a patrician family; his rights are clear, but the added weight of your support would be very welcome. Respect for the memory of his ancestors, and no mere greed, inclines him to this purchase, for down to the recent death of his stepfather the whole property belonged to his family. He is of an economical turn of mind, but not the man to covet his neighbour's goods; the loss of a former possession in itself troubles him little; the point of honour decides him; it is not avarice which prompts his action, but the shame of inactivity. Deign therefore to consider what you owe to your own credit, to his honourable desire, to my friendly intercession; help to secure for him this chance of rounding off the estate.

These paternal acres are not just casually known to him; he crawled upon them as an infant hardly weaned. He will make little profit by their recovery; but he feels that it would have been too contemptible not to make the effort. Whatever favour you may be able to accord to one whom I regard as a brother in years, a son by profession, a fellow citizen by origin, and a friend by loyalty, I shall be as much beholden as if the matter turned to my own particular advantage. Farewell. ${ }^{37}$

At the very beginning of the letter, we see an extensive introduction in which the author generally presents the motives that are intended to encourage Hypatius to respond positivelyalthough this has not yet been presented. The matter, as one may see in the second part of the letter, is of economic nature, but Donidius - as Sidonius carefully emphasises - is not only about domestic benefits. The bishop emphasises the dignity and nobility of the recommended person, as well as his admiration and praise for the nobility of the habits of Hypatius, the integrity of whom would be sufficient to go to the requester (this is already an element of captatio benevolentiae). It is the bonds of sympathy that connect Donidius and Sidonius, that make the requester seek intercession, and both friends - Donidius and Sidonius - turn to Hypatius and become his debtors.

This extensive introduction is followed by the presentation of the essence of the problem and the request: Donidius is seeking to buy a half of a certain estate because of the memory of his grandfather, all of which belonged to his family during his lifetime. Sidonius is very keen to emphasise this noble motif of Donidius' efforts, not the economic considerations of

\footnotetext{
37 Si uir spectabilis morumque uestrorum suspector admiratorque Donidius solam rationem domesticae utilitatis habuisset, satis abundeque sufficeret fides uestra commodis suis, etsi nullus intercessor accederet. Sed amore meo ductus est, ut, quod ipse per se impetrauerat, me faceret postulare. Itaque nunc honori uestro hic quoque cumulus accrescit, quod duo efficimur debitores, cum tamen unus e nobis beneficium consequatur. Eborolacensis praedii etiam ante barbaros desolatam medietatem, quae domus patriciae iura modo respicit, suffragio uestro iuri suo optat adiungi. Neque ad hanc nundinationem stimulo cupiditatis sed respectu auitae recordationis adducitur. Siquidem fundi ipsius integritas familiae suae dominium usque in obitum uitrici nuper uita decedentis aspexit; nunc autem uir alieni non appetens, sui parcus possessionis antiquae a se alienatae non tam damno angitur quam pudore; quam ut redimere conetur non auaritiae uitio sed uerecundiae necessitate compellitur. Tribuere dignare uotis suis, precibus meis, moribus tuis, ut ad soliditatem ruris istius te patrocinante perueniat, cui rem parentum sibique non solum notam uerum etiam inter lactantis infantiae rudimenta reptatam sicut recepisse parum fructuosum, sic non emeruisse nimis uidetur ignauum. Ego uero tantum obstringar indultis ac si meae proficiat peculiariter proprietati, quicquid meus aetate frater, professione filius, loco ciuis, fide amicus acceperit. Vale; Sidonius Apollinaris, Epistula III 5, ed. A. Loyen, vol. 2, pp. 91-92, translated by M. Brożek, p. 47. [TN English translation of the quote: Sidonius Apollinaris, Letters. Tr. O.M. Dalton (1915)].
} 
the entire operation. Therefore, he emphasises several times that Donidius does not only have a domestic advantage in mind $^{38}$, argues that no mere greed, inclines him to this purchase [...] the point of honour decides him, it is not avarice which prompts his action, but the |72 shame of inactivity ${ }^{39}$. The only remaining important motive was the nobility of the recommended person, his respect for the memory of his ancestors and concern for his good name.

In the last part of the letter, Sidonius sends a request to Hypatius for help in the matter presented and motivated by such noble considerations, supplementing it with another mention of the recipient's righteousness and presenting his personal commitment to it, and underlining once again the bonds connecting him with the recommended Donidius: one whom I regard as a brother in years, a son by profession, a fellow citizen by origin, and a friend by loyalt $y^{40}$

Another example - but already bearing the hallmarks of the episcopal period of Sidonius' life is the letter V 1, addressed to Petronius ${ }^{41}$, recommending deacon Vindictus who also needed help in the matter of an estate. Sidonius begins the letter with a praise for the addressee: on the one hand, he is happy to note that Petronius reads his letters with patience and pleasure. The bishop of Avernum also notes the literary talent and works of the addressee, which makes it all the more commendable that Petronius, himself distinguished by his great talent, can be a lover of someone else's talent ${ }^{42}$.

After this initial captatio benevolentiae, Sidonius sends a request for help to the bearer of the letter - Vindictus, informing about his religiosity, family ties with Sidonius and belonging to the clergy:

I commend to you my friend Vindictus, a man of piety, and admirably suited for the dignity of deacon which he has recently attained ${ }^{43}$.

This is a short and basically the only justification for the request because Sidonius immediately informs that he also gives his letters as a gift that Petronius asked for. He devotes a little more attention to outlining the essence of the problem, which -as he informs - lies in the possible difficulties in obtaining the legacy of inheritance that may arise as a result of violent deception, but does not explain in more detail this possible deception and threat. The letter is from the turn of $470 / 471^{44}$, so it was written, as analysed above, at the beginning of the episcopate and contains a new element: it recommends a clergyman and contains religious elements contained in the belief that Petronius is the only person who can remedy the matter in question, post opem Christi ${ }^{45}$, and the information about the person is limited

\footnotetext{
38 Ibidem III 5,1, ed. A. Loyen, vol. 2, p. 91, translated by M. Brożek, p. 47.

39 All three quotes were taken from: Ibidem III 5,2, ed. A. Loyen, vol. 2, p. 91, translated by M. Brożek, p. 47. [TN English translation of the quote: Sidonius Apollinaris, Letters. Tr. O.M. Dalton (1915)].

40 Meus aetate frater, professione filius, loco ciuis, fide amicus; Ibidem III 5,3, ed. A. Loyen, vol. 2, p. 92, translated by M. Brożek, p. 47.

41 The addressee of letters II 5, VIII 1; mentioned in the letter I 7.4, a member of the mission team sent to the Caesar in relation to the complaint about the prefect of the Province of Gaul Arvandus.

42 Cf. Ibidem V 1,1, ed. A. Loyen, vol. 2, p. 173.

43 Commendo Vindicium necessarium meum, uirum religiosum et leuiticae dignitati, quam nuper indeptus est, accommodatissimum; ibidem V 1,2, ed. A. Loyen, p. 173, translated by M. Brożek, p. 86. [TN English translation of the quote: Sidonius Apollinaris, Letters. Tr. O.M. Dalton (1915)].

44 Cf. Chmielewski, trans. Cf. A. Loyen, Chronologie des lettres, in: Sidoine Apollinaire, vol. 2, pp. 255.

45 Cf. Sidonius Apollinaris, Epistula V 1,3, ed. A. Loyen, vol. 2, p. 174.
} 
to the information presented above, that the recommended person is a religious man, very suitable for the priesthood, which he recently obtained ${ }^{46}$.

Similarly, in the letter VI 10, Sidonius recommends the bearer of the letter, not mentioned by name, to Bishop Censorius, informing that he belongs to the clergy and escaping with his family from the devastation caused by Goths, was forced into the recipient's territory ${ }^{47}$. In the VI letter $8^{48}$ he recommends the teacher - the bearer of the letter and indicates:

As his name is now entered in the roll as Reader, you will see that I have had to give him in addition to an ordinary introduction as citizen, a canonical letter as a clerk ${ }^{49}$.

In several letters, Sidonius recommends unspecified bearers of letters. This is the case with the letter VII 4 to Bishop Fonteius, in which at the same time he thanks for the benevolent reception of Vindicius (without informing whom he is talking about) and the care provided for his relatives, and also recommends the not-named bearer of the letter ${ }^{50}$; in the letter VI 5 , recommending the bearer of the letter, he asks to provide him help in traveling ${ }^{51}$; in the letter VII 11 (10) he recommends the bearer of the letter, adding only that the person himself will explain the issue that requires his help ${ }^{52}$, and in the letter VI 3 he asks him to help the bearer of the letter with a property ${ }^{53}$.

The letter VI 4 to Bishop Lupus also recommends bearers but Sidonius presents the matter more extensively. The problem concerns the kidnapping of a woman during a robbery raid; she was sold and then was forced to work at a certain estate. Sidonius first presents the matter to the bishop, writing:

By the fortunate fact of your presence, you will be able, if you think fit, to see the parties confronted, and use your personal influence to investigate the whole course of the outrage $e^{54}$.

He then intervenes more directly and suggests that Lupus should lead to a court settlement in order to diminish the misery of one party and the guilt of the other ${ }^{55}$.

\footnotetext{
46 Cf. ibidem V 1,2, ed. A. Loyen, vol. 2, p. 173, tłum. M. Brożek, p. 86.

47 Cf. ibidem, Epistula VI 10, ed. A. Loyen, vol. 3, p. 24, translated by M. Brożek, p. 111.

48 The letter from the year 476 or 477; cf.. A. Loyen, Chronologie des lettres, Sidoine Apollinaire, vol. 3: Correspondance livres 6-9, Paris 2003, p. 213.

49 et, quia nomen eiusdem lectorum nuper albus accepit, agnoscitis profecturo ciui me epistulam, clerico debuisse formatam; Sidonius Apollinaris, Epistula VI 8,2, ed. A. Loyen, vol. 3, p. 20, translated by M. Brożek, p. 111. [TN English translation of the quote: Sidonius Apollinaris, Letters. Tr. O.M. Dalton (1915)].

50 Cf. ibidem VII 4, ed. A. Loyen, vol. 3, pp. 39-40.

51 Cf. ibidem VI 5, ed. A. Loyen, vol. 3, p. 17.

52 Cf. ibidem VII 11 (10),2, ed. A. Loyen, vol. 3, pp. 63.64.

53 Cf. ibidem VI 3; ed. A. Loyen, vol. 3, pp. 13-14.

54 Auctoritas personae, opportunitas praesentiae tuae inter coram positos facile ualebit, si dignabitur, senem totius indagare uiolentiae; ibidem VI 4,2, ed. A. Loyen, vol. 3, p. 16; translated by M. Brożek, p. 108. [TN English translation of the quote: Sidonius Apollinaris, Letters. Tr. O.M. Dalton (1915)]

55 Sed quia iudicii uestri medicinam expetunt ciuilitatemque, qui negotium criminale parturiunt, uestrarum, si bene metior, partium pariter et morum est, aliqua indemni compositione istorum dolori, illorum periculo subuenire et quodam salubris sententiae temperamento hanc partem minus afflictam, illam minus ream et utramque plus facere securam; ibidem VI 4,3, ed. A. Loyen, vol. 3, p. 16, translated by M. Brożek, pp. 108-109. Further notes about the letter see: L. Furbetta, La Lettre, p. 353.
} 
He also asks the unknown Bishop Pragmatius to mediate and settle the dispute regarding family matters and inheritance between Eutropia - the venerable widow praised by Sidonius and priest Agrippinus ${ }^{56}$.

He also writes two letters recommending Jews ${ }^{57}$, in both, as we have learnt above, leaving the interested parties to submit their request themselves. He only informs that the second case is about a neophyte who was recently baptised.

The provided analysis of Sidonius' letters of recommendation allows for some further conclusions to be drawn. Sidonius writes letters of recommendation in various periods of his activity and addresses a variety of issues: family and personal, political, judicial, and religious ones. When looking at the information about the dating of letters, it is easy to notice that these letters come from the final years of the secular life of Sidonius as well as from the times of his episcopate, hence they are a sign of the power and influence that Sidonius gained at that time ${ }^{58}$.

Our author declares his willingness to imitate the great masters of epistolography, who for him were Cicero, Quintus Symmachus, Gaius Plinius, and Julius Titianus. He maintains the structure and rules of writing letters of recommendation developed and used by these authors in his letters, although he diversifies them and, depending on the situation, puts emphasis on various elements of commendatio, places them in different parts and uses different arguments.

Engaged in public service, Sidonius, while writing letters of recommendation, emphasises the very high origin and personality traits of the recommended individuals, presenting their relatives and merits, listing the features that were generally to show them as noble people.

After receiving episcopal ordination, the subject matter, recipients, arguments and the composition of the recommendations change. During this period, letters of recommendation dealing with political career or public functions are not present any longer as opposed to the letters of recommendation of the Church community members. In the letters from this period, the argument and presentation of the recommended person are very much reduced, sometimes restricted only to information that a person is a clergyman or that the recommended individual is a bearer of the letter. The subject of the request itself is also given very synthetically or even omitted. Instead of a request or information what favour or help the commendatus expects, there is only a mention that all necessary explanations will be given by the person himself.

In conclusion, it is plausible to state that in the light of the analysed letters of recommendation, Sidonius appears as a representative of society, who by obvious means of recommendations depicts the expression of social life and relationships between the people of the period. However, in his work and in the application of recommendations, he is creative and dynamic, therefore his letters of recommendation remain an important source of knowledge on both the era and society he represents.

56 Sidonius Apollinaris, Epistula VI 2, ed. A. Loyen, vol. 3, pp. 11-12.

57 Sidonius Apollinaris, Epistula VI 11 (ed. A. Loyen, vol. 3, p. 25) and VIII 13 (ed. A. Loyen, vol. 3, pp. 121-122).

58 L. Furbetta (La lettre, p. 346) underscores that power and influence are crucial conditions which made the writing of the letters possible. 


\section{Letters of Recommendation of Sidonius Apollinaris - the Legacy of Tradition and the Challenge of Transformations \\ Summary}

The article presents the letters of Sidonius Apollinaris - Gallo-Roman aristocrat, poet and bishop. The study aims at analysing the letters of Sidonius from the point of view of their purpose, the models used, the argumentation, and the list of recipients to whom the letters are addressed. On the one hand, it shows that Sidonius remaining faithful to his masters in epistolography (Cicero, Pliny the Younger, Symmachus), while on the other hand, was able to change the form of letters according to the situation. The paper also allows us to discern the changes that took place in the works of Sidonius after his ordination.

Keywords: Sidonius Apollinaris, Letters, Tradition, Innovation

Note about the author: fr dr Tomasz Skibiński SAC, patrologist and historian specialising in the study of late antiquity and the early Middle Ages in the Western Roman Empire and succession kingdoms in the West. The Deputy Director of the Institute of Historical Sciences at the Cardinal Stefan Wyszyński University in Warsaw. 